\title{
Zagadnienia jakości badań nieniszczących Wymagania ogólne w zakresie kompetencji laboratoriów badawczych
}

\section{Quality issues of non-destructive testing - general requirements for the competence of testing laboratories}

\section{Streszczenie}

W referacie zaprezentowano zagadnienia jakości badań nieniszczących omawiając kluczowe elementy systemu badań nieniszczących, w ujęciu spełnienia wymagań PN-EN ISO/IEC 17025. Przekrojowo, w formie przeglądu aktualnych wydań norm, przedstawiono główne aspekty systemu badań laboratoryjnych ze szczególnym naciskiem na kryteria oceny wyników badań, na przykładzie badań złączy spawanych oraz zasad protokołowania.

W opracowaniu przedstawiono również aktualne warunki i wymagania dla laboratoriów, które są oceniane w procesie uznawania laboratoriów, uzupełniając je najczęściej pojawiającymi się spostrzeżeniami zespołów oceniających laboratoria.

Słowa kluczowe: badania nieniszczące, złącza spawane, normy, uznawanie laboratoriów
Abstract

The paper presents the issues of quality of NDT discussing the key elements of the non-destructive testing system, in terms of meeting the requirements of PN-EN ISO/IEC 17025. Across the board, in the form of a review of the current editions of standards, outlined the main aspects of the laboratory tests with particular emphasis on the evaluation criteria of research results, on the basis of testing of welded joints and the rules for logging.

The current conditions and requirements for laboratories that are evaluated in the laboratories recognition process performed by UDT are discussed, supplementing the most frequently occurring insights of laboratories assessing teams.

Keywords: non-destructive testing, evaluation criteria, welded joints, standards, recognition of laboratories

\section{Wstęp}

Badania nieniszczące to główny element nadzoru nad urządzeniami technicznymi w celu zapewnienia bezpieczeństwa w sferze gospodarczej oraz ochrony środowiska naturalnego. NDT zapewniają możliwość badania stanu obiektów, które będą eksploatowane po badaniu, bez potrzeby ingerencji w ich strukturę. Wynik badań stanowi podstawę do podjęcia decyzji co do dalszych losów urządzenia, niezależnie, czy decyzję podejmuje właściciel/użytkownik/wytwórca urządzenia, czy tzw. strona trzecia. Badania takie powinny być wykonywane przez kompetentne laboratoria badawcze.

Biorąc pod uwagę odpowiedzialność inspektorów UDT za decyzje podejmowane na podstawie ich wyników, to UDT musi akceptować laboratoria i wyniki ich badań.

\section{Metody badań - norma, procedura i inne specyfikacje}

Metody i techniki badań nieniszczących stosowane w laboratorium powinny spełniać wymagania klienta, lecz co najważniejsze, powinny być odpowiednie dla badań, których wykonania podejmuje się laboratorium. W przypadku, gdy klient nie określi metody badania, laboratorium może wybrać metodę znormalizowaną, metodę określoną odpowiednią specyfikacją techniczną lub opracować lub zaadoptować metodę własną. We wszystkich tych przypadkach, laboratorium powinno uzgodnić z klientem wybraną metodę czy technikę badania, potwierdzić możliwość realizowania metody znormalizowanej lub potwierdzić/udokumentować odpowiedniość metody nieznormalizowanej czy własnej.

Dla metod znormalizowanych, w przypadku np. nowelizacji wydania normy, należy powtórzyć potwierdzenie możliwości realizacji metody w laboratorium. Laboratorium powinno zapewnić klienta, że stosuje aktualne wydanie normy oraz, że jest zdolne do wykonywania badań zgodnie $z$ ta normą. W zakresie norm badań nieniszczących obserwuje się ostatnio duże zmiany, w ślad za rozwojem technik badawczych., Może to prowadzić do nieporozumień pomiędzy klientem, a laboratorium. Najistotniejsze jednak jest to, aby na etapie

Dr inż. Grzegorz Wojas - Urząd Dozoru Technicznego.

Autor korespondencyjny/Corresponding author. grzegorz.wojas@udt.gov.pl 
Tablica I. Normy badań nieniszczących

Table I. Non-destructive testing standards of welds

\begin{tabular}{|c|c|c|c|}
\hline NDT & Norma wycofana & Zastąpiona przez & Tytuł normy \\
\hline & PN-EN 12062:2000 & PN-EN ISO 17635:2010 & Badania nieniszczące spoin. Zasady ogólne dotyczące metali \\
\hline & PN-EN ISO 6520-1:2007 & PN-EN ISO 6520-1:2009 & $\begin{array}{l}\text { Spawanie i procesy pokrewne. Klasyfikacja geometrycznych } \\
\text { niezgodności spawalniczych w metalach. Część } 1\end{array}$ \\
\hline & PN-EN ISO 5817:2009 & PN-EN ISO 5817:2014 & $\begin{array}{l}\text { Złącza spawane ze stali, niklu, tytanu i ich stopów. Poziomy } \\
\text { jakości według niezgodności spawalniczych }\end{array}$ \\
\hline \multirow{2}{*}{ VT } & PN-EN 970:1999 & PN-EN ISO 17637:2011 & $\begin{array}{l}\text { Spawalnictwo - Badania nieniszczące złączy spawanych - Bada- } \\
\text { nia wizualne }\end{array}$ \\
\hline & PN-EN ISO 5817:2009 & PN-EN ISO 5817:2014 & $\begin{array}{l}\text { Złącza spawane ze stali, niklu, tytanu i ich stopów. Poziomy jako- } \\
\text { ści według niezgodności spawalniczych }\end{array}$ \\
\hline \multirow{3}{*}{ PT } & PN-EN 571-1:1999 & PN-EN ISO 3452-1:2013-08 & Badania nieniszczące Badania penetracyjne Część 1: Zasady ogólne \\
\hline & PN-EN ISO 3452-2:2002 & PN-EN ISO 3452-2:2006 & $\begin{array}{l}\text { Badania nieniszczące. Badania penetracyjne. Część 2: Badania } \\
\text { materiałów penetracyjnych }\end{array}$ \\
\hline & PN-EN 1289:2000 & PN-EN ISO 23277:2010 & $\begin{array}{l}\text { Badania nieniszczące złączy spawanych. Badania penetracyjne } \\
\text { złączy spawanych - Poziomy akceptacji }\end{array}$ \\
\hline \multirow{2}{*}{ MT } & PN-EN 1290:2000 & PN-EN ISO 17638:2010 & Badanie nieniszczące spoin. Badanie magnetyczno- proszkowe \\
\hline & PN-EN 1291:2000 & PN-EN ISO 23278:2010 & $\begin{array}{l}\text { Badania magnetyczno-proszkowe złączy spawanych. Poziomy } \\
\text { akceptacji }\end{array}$ \\
\hline \multirow{3}{*}{ UT } & PN-EN 1714:2002 & PN-EN ISO 17640:2011 & $\begin{array}{l}\text { Badania nieniszczące złączy spawanych. Badanie ultradźwiękowe } \\
\text { złączy spawanych }\end{array}$ \\
\hline & PN-EN 1713:2002 & PN-EN ISO 23279:2010 & $\begin{array}{l}\text { Badania nieniszczące spoin. Badania ultradźwiękowe. Charakte- } \\
\text { rystyka wskazań w spoinach }\end{array}$ \\
\hline & PN-EN 1712:2001 & PN-EN ISO 11666:2011 & $\begin{array}{l}\text { Badanie nieniszczące złączy spawanych. Badania ultradźwięko- } \\
\text { we złączy spawanych - Poziomy akceptacji }\end{array}$ \\
\hline \multirow{2}{*}{$\mathrm{RT}$} & PN-EN 1435:2001 & PN-EN ISO 17636-1:2013-06 & $\begin{array}{l}\text { Badania nieniszczące złączy spawanych - Badania radiograficz- } \\
\text { ne złączy spawanych }\end{array}$ \\
\hline & PN-EN 12517-1:2008 & PN-EN ISO 10675-1:2013-12E & $\begin{array}{l}\text { Badania nieniszczące spoin. Kryteria akceptacji badań radiogra- } \\
\text { ficznych. Część 1: Stal, nikiel, tytan i ich stopy }\end{array}$ \\
\hline
\end{tabular}

Tablica II. Normy badania i oceny, a poziomy jakości

Table II. Standards vs quality levels

\begin{tabular}{|c|c|c|}
\hline & & Zasady badania \\
\hline Lp. & Metoda & Norma dotycząca: \\
\hline \multirow{4}{*}{1} & \multirow{4}{*}{ VT } & Badanie \\
\hline & & $\begin{array}{l}\text { PN-EN 13018:2004 Badania wizualne. Zasady ogólne } \\
\text { PN-EN ISO 17637:2011 Badania złaczy spawanych. Badania wizualne }\end{array}$ \\
\hline & & Ocena \\
\hline & & $\begin{array}{l}\text { PN-EN ISO 5817:2014 Złącza spawane ze stali, niklu, tytanu i ich stopów. } \\
\text { Poziomy jakości wedhug niezgodności spawalniczych }\end{array}$ \\
\hline \multirow{4}{*}{2} & \multirow{4}{*}{ PT } & Badanie \\
\hline & & $\begin{array}{l}\text { PN-EN ISO 3452-1:2013-08 Badania nieniszczące. Badania penetracyjne. } \\
\text { Czéść 1: Zasady ogólne }\end{array}$ \\
\hline & & Ocena \\
\hline & & $\begin{array}{l}\text { PN-EN ISO 23277:2010 Badanie nieniszczące spoin. Badanie penetracyjne } \\
\text { spoin. Poziomy akceptacji }\end{array}$ \\
\hline \multirow{4}{*}{3} & \multirow{4}{*}{ MT } & Badanie \\
\hline & & $\begin{array}{l}\text { PN-EN ISO 17638:2010 Badanie nieniszczące spoin. Badanie } \\
\text { magnetyczno-proszkowe }\end{array}$ \\
\hline & & Ocena \\
\hline & & $\begin{array}{l}\text { PN-EN ISO 23278:2010 Badanie nieniszczace spoin. Badanie } \\
\text { magnetyczno-proszkowe spoin. Poziomy akceptacji }\end{array}$ \\
\hline \multirow{4}{*}{4} & \multirow{4}{*}{ RT } & Badanie \\
\hline & & $\begin{array}{l}\text { PN-EN ISO 17636-1:2013-06 Badania nieniszczące złączy spawanych. } \\
\text { Badania radiograficzne złączy spawanych }\end{array}$ \\
\hline & & Ocena \\
\hline & & $\begin{array}{l}\text { PN-EN ISO 10675-1:2013-12E Badania nieniszczące spoin. Kryteria } \\
\text { akceptacji badań radiograficznych. Część 1: Stal, nikiel, tytan i ich stopy }\end{array}$ \\
\hline \multirow{4}{*}{5} & \multirow{4}{*}{ UT } & Badanie \\
\hline & & $\begin{array}{l}\text { PN-EN 583-1:2001 Badania nieniszczące. Badania ultradźwiękowe. Zasady } \\
\text { ogólne } \\
\text { PN-EN ISO 17640:2011 Badania nieniszczące złączy spawanych. Badanie } \\
\text { ultradźwiękowe złączy spawanych }\end{array}$ \\
\hline & & Ocena \\
\hline & & $\begin{array}{l}\text { PN-EN ISO 11666:2011 Badanie nieniszczące złączy spawanych. Badania } \\
\text { ultradźwiękowe złączy spawanych - Poziomy akceptacji }\end{array}$ \\
\hline
\end{tabular}

\begin{tabular}{|c|c|c|}
\hline \multicolumn{3}{|c|}{ Kryteria jakości wg normy } \\
\hline Poziom jakości & $\begin{array}{c}\text { Technika i poziom (klasa) } \\
\text { badania }\end{array}$ & Poziom akceptacji \\
\hline PN-EN ISO 5817:2014 & PN-EN ISO 17637:2011 & PN-EN ISO 5817:2014 \\
\hline B & NIE OKREŚLONO & B \\
\hline C & NIE OKREŚLONO & C \\
\hline D & NIE OKREŚLONO & D \\
\hline
\end{tabular}

\begin{tabular}{|c|c|c|}
\hline \multicolumn{3}{|c|}{} \\
\hline PN-EN ISO 5817:2014 & PN-EN ISO 3452-1:2013 & PN-EN ISO 23277:2010 \\
\hline B & NIE OKREŚLONO & $\mathbf{2}$ X \\
\hline C & NIE OKREŚLONO & $\mathbf{2}$ X \\
\hline D & NIE OKREŚLONO & $\mathbf{3 X}$ \\
\hline
\end{tabular}

Poziomy akceptacji 2 i 3 moga być zapisywane ze znakiem $X$, co oznacza, że wskazania liniowe nalezy ocenić wg poziomu akceptacji $1, t z n .1 \leq 2 \mathrm{~mm}$

\begin{tabular}{|l|c|c|}
\hline PN-EN ISO 5817:2014 & PN-EN ISO 17638:2010 & PN-EN ISO 23278:2010 \\
\hline
\end{tabular}

\begin{tabular}{c|c|c|}
\hline PN-EN ISO 5817:2014 & PN-EN ISO 17638:2010 & PN-EN ISO 23278:2010 \\
\hline & NIE OKREŚLONO &
\end{tabular}

\begin{tabular}{|c|c|c|}
\hline $\mathbf{B}$ & NIE OKREŚLONO & $\mathbf{2} \mathbf{X}$ \\
\hline $\mathbf{C}$ & NIE OKREŚLONO & $\mathbf{2} \mathbf{X}$ \\
\hline $\mathbf{D}$ & NIE OKREŚLONO & $\mathbf{3 \mathbf { X }}$ \\
\hline Poziomy akceptacji 2 i 3 moga być zapisywane ze znakiem $X$, tzn wskazania liniowe nalezy ocenić
\end{tabular}

Poziomy akceptacji 2 i 3 moga być zapisywane ze znakiem $X$, tzn wskazania liniowe nalezy ocenić wg poziomu akceptacji $1, t z n .1 \leq 1,5 \mathrm{~mm}$

\begin{tabular}{|c|c|c|}
\hline PN-EN ISO 5817:2014 & PN-EN ISO 17636-1:2013-06 & PN-EN ISO 10675-1:2013-12E \\
\hline
\end{tabular}

\begin{tabular}{|c|c|c|}
\hline B & B & 1 \\
\hline C & $\mathbf{B}^{1}$ & 2 \\
\hline D & A & 3 \\
\hline
\end{tabular}

\begin{tabular}{|c|c|}
\hline D & A \\
\hline 1) Minimalna ilość ekspozycji dla zlaczy obwodowych wg wymagań klasy A, wg PN-EN ISO 17636
\end{tabular} \begin{tabular}{||c|c|c|}
\hline PN-EN ISO 5817:2014 & PN-EN ISO 17640:2011 & PN-EN ISO 11666:2011 \\
\hline & &
\end{tabular}

\begin{tabular}{|l|c|c|}
\hline B 5817:2014 & PN-EN ISO 17640:2011 & PN-EN ISO 11666:2011 \\
\hline C & Co najmniej B & 2 \\
\hline D & Co najmniej A & 3 \\
\hline magane jest charakteryzowanie wskazań, musi być zastosowana ISO 23279 \\
jest zalecane, ale moźe być wymagane w specyfikacji (z takimi samymi wymaganiami jak \\
ośsi $C$ )
\end{tabular}
poziom jakosici () 
uzgodnień mówić jednym językiem i stawiać zrozumiałe dla obu stron wymagania i kryteria oceny.

W tablicy I przedstawiono ostatnio zmienione normy najczęściej stosowanych badań nieniszczących. Natomiast w tablicy II zestawiono normy badań i normy dotyczące kryteriów akceptacji, dotyczące złączy spawanych.

\section{Personel - czyli nie tylko co i jak, ale kto?}

$\mathrm{Na}$ personelu wykonującym badania nieniszczące spoczywa duża odpowiedzialność - nie tylko wobec pracodawców lub klientów, lecz także wobec zasad dobrej praktyki. Personel wykonujący badanie powinien być niezależny i wolny od nacisków ekonomicznych, w przeciwnym razie będzie zagrożona rzetelność uzyskanych wyników badania. Powinien być świadomy również znaczenia swego podpisu oraz konsekwencji nieprawidłowych wyników badania dla bezpieczeństwa, zdrowia publicznego i środowiska.

Główne elementy systemu badawczego, czyli procedura / wyposażenie badawcze, są ściśle związane z kompetencjami personelu badawczego - trzeciego elementu systemu badawczego. Kompetencje czyli wiedza, doświadczenie i umiejętności ich stosowania mają wpływ na cały proces badawczy:

- właściwy wybór metody / techniki badania,

- opracowanie właściwej dla określonego przypadku - obiektu- procedury / instrukcji badania,

- określenie odpowiedniego wyposażenia badawczego oraz materiałów do badań,

- określenie parametrów badania i warunków wykonania badania,

- ustalenie dokumentów odniesienia, postępowania podczas badania i określenie wymagań w odniesieniu do kompetencji personelu wykonującego badanie.

Ze względu na znaczenie wyboru metody badawczej dla w celu wykrycia określonej, spodziewanej nieciągłości, PNEN ISO 9712 kompetencje w tym zakresie nadaje personelowi z 3. stopniem. Wynika to z faktu, iż są to osoby, które posiadając certyfikat 3 . stopnia $w$ danej metodzie, jednocześnie posiadają kompetencje na poziomie 2. stopnia w co najmniej trzech innych metodach NDT, co wynika ze zdania przez nich egzaminu podstawowego, tzw. Basic w zakresie takich metod.

Do określania ograniczeń w stosowaniu metody oraz wyboru techniki badania może być uprawniony przez pracodawcę personel z 2.stopniem w tej metodzie. Możliwość upoważnienia przez pracodawcę do zatwierdzania procedur badawczych norma przyznaje wyłącznie personelowi z 3.stopniem certyfikacji.

W praktyce instrukcje opracowują i zatwierdzają osoby z 2.stopniem, które podczas procesu certyfikacji (egzaminu) dowiodły umiejętności opracowywania instrukcji. W niektórych przypadkach jednostki certyfikujące udzielają certyfikacji 2.stopnia bez prawa opracowywania/ zatwierdzania instrukcji badawczej.

Uzyskanie certyfikatu nie jest jednoznaczne z upoważnieniem do wykonywania badań u danego pracodawcy, ponieważ jednostka certyfikująca wydająca certyfikat potwierdza kompetencje techniczne osoby certyfikowanej, ale nie bierze odpowiedzialności za wyniki badań wykonywanych przez tę osobę. Taką odpowiedzialność PN-EN ISO 9712 przypisuje pracodawcy osoby certyfikowanej. Dlatego też tylko pracodawca może upoważnić swojego pracownika do wykonywania czynności właściwych dla określonego stopnia posiadanego certyfikatu, za które bierze całkowitą odpowiedzialność. Osoba certyfikowana odpowiada za swoje działania wyłącznie wobec pracodawcy, który upoważnił ją do wykonywania czynności z zakresu certyfikatu.
Kompetencje powinny być ciągle utrzymywane, nadzorowane i aktualizowane, gdyż zaniedbanie tego obowiązku prowadzi do pogorszenia jakości i rzetelności wyników badań na skutek:

- rutyny, z której wynika niekiedy lekceważenie wymagań norm / procedur / instrukcji,

- złych nawyków czy nieprzestrzegania bhp,

- braku znajomości nowych technik i metod badawczych i "cofania się"; stąd potrzeba ciągłego szkolenia,

- pogarszającej się z czasem zdolności widzenia bliskiego; istotne jest więc przestrzeganie wymagania odnośnie badania ostrości widzenia i stosowania odpowiedniej korekcji, jeśli jest wymagana.

\section{Wykonywanie badań - czyli tak mówi procedura}

Procedura badawcza jako pisemny dokument opisujący wszystkie istotne parametry i środki ostrożności jakich należy przestrzegać podczas wykonywania badania, powinny być zatwierdzone przez personel z 3.stopniem i zawierać, jako niezbędne minimum, informacje jakie pokazano na rysunku 1.

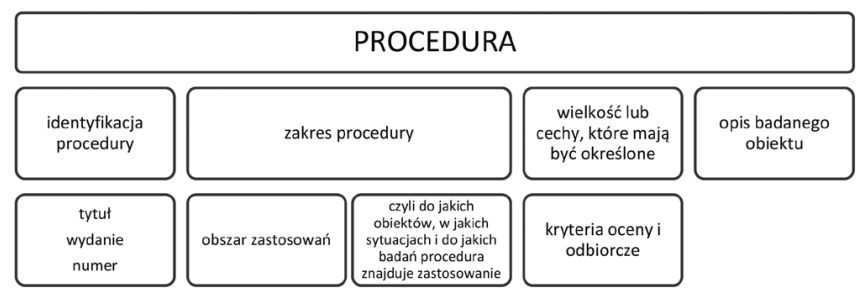

Rys. 1. Minimalna zawartość procedury badawczej

Fig. 1. Testing procedure content

Procedury znormalizowanych metod i technik NDT nie muszą być sporządzania w formie pisemnej, jeśli normy zawierają pełne informacje umożliwiające przeprowadzenie badania i mogą być w całości stosowane przez personel NDT, wykonujący badania. W niektórych przypadkach może wystąpić potrzeba uzupełnienia czy wyjaśnień tekstu normy - można to wprowadzić w formie uproszczonej procedury, w której norma (lub normy, jeśli dołączymy np. normę terminologiczną)będą powołane. Modyfikacja lub rozszerzenie zakresu normy, zmiana jej zakresu stosowania na inne wyroby, materiały lub grubości, nie musi powodowi konieczności opracowywania własnej procedury. W takim przypadku proceduraznormalizowana powinnabyćuzupełnionaotec hniczneuzasadnienietakiejmodyfikacjiczy rozszerzenia oraz o procedurę i wynik walidacji w zakresie, w którym ją zmodyfikowano czy rozszerzono.

W tym miejscu warto przypomnieć, że walidacja stanowi potwierdzenie przez zbadanie i przedstawienie obiektywnego dowodu, że zostały spełnione szczególne wymagania dotyczące konkretnie zamierzonego zastosowania [2]. Walidację metod i technik badawczych:

- własnych, opracowanych przez laboratorium,

- nieznormalizowanych, opublikowanych przez organizacje techniczne,

- opisanych w pracach naukowych lub czasopismach naukowych,

- opracowanych i zalecanych przez producenta wyposażenia do badań,

- znormalizowanych, które zostały rozszerzone lub zmodyfikowane,

- znormalizowanych, stosowanych przez laboratorium poza zakresem ustalonym normą,laboratorium powinno przeprowadzać we własnym zakresie, a jej wynik udokumentować. 


\section{Wyposażenie do badań - czyli skalowanie, wzorcowanie czy sprawdzenie?}

Wyposażenie do badań, pomiarowe i badawcze, powinno zapewniać wymaganą dokładność, spełniać odpowiednie wymagania norm i specyfikacji dotyczących badań, być jednoznacznie zidentyfikowane, być sprawdzone, a jeśli jest to wymagane - wzorcowane przed użyciem, obsługiwane (eksploatowane i konserwowane) przez upoważniony personel, nadzorowane zgodnie z ustalonym programem, Powinien być czytelny status nadzoru, $\mathrm{np}$. wyposażenie powinno być opatrzone odpowiednimi etykietami, oznaczeniem kodowym, itp. Dla wyposażenia najistotniejszego dla danego badania, powinny być sporządzane i utrzymywane zapisy obejmujące:

- lokalizację, daty i wyniki sprawdzeń lub wzorcowań,

- daty kolejnych sprawdzeń lub wzorcowań,

- plany konserwacji, modyfikacje, uszkodzenia, naprawy itd.

Zapisy mogą być w formie tabel, rejestrów, lub specjalnych programów elektronicznych.

Laboratorium powinno ustalić programy sprawdzania lub wzorcowania oraz mieć procedury dotyczące bezpiecznego użytkowania, transportowania, magazynowania i konserwacji wyposażenia badawczego.

W laboratoriach NDT obserwuje się często zamienne stosowanie terminów „wzorcowanie” i "skalowanie”. Te dwa terminy nie powinny być mylone, są to bowiem pojęcia bardzo od siebie odległe, choć oba odnoszą się do przyrządów pomiarowych. W wyposażeniu badawczym stosowanym w defektoskopii - przykładowo w defektoskopach ultradźwiękowych, zwykle mamy do czynienia z ich skalowaniem, a nie wzorcowaniem, choć w niektórych przypadkach wzorcowanie jest nieodzowne (np. przy użyciu defektoskopu ultradźwiękowego do pomiaru grubości ścianki, przy pomiarze natężenia przecieku helowym wykrywaczem nieszczelności itp.). W normach dotyczących badań nieniszczących również występuje pojęcie skalowania przeprowadzanego przy użyciu próbek odniesienia lub próbek wzorcowych (wzorców). Stąd np. w badaniach ultradźwiękowych występuje "skalowanie podstawy czasu" przeprowadzane przy użyciu wzorca Nr 1 lub Nr 2. Zatem, w celu uporządkowania:

Wzorcowanie (kalibracja) jest to zbiór operacji, ustalających w określonych warunkach, relacje między wartościami wielkości mierzonej, wskazanymi przez przyrząd pomiarowy, albo wartościami reprezentowanymi przez wzorzec miary lub materiał odniesienia, a odpowiednimi wartościami wielkości realizowanymi przez wzorce jednostki miary.

Skalowanie zaś (przyrządu pomiarowego) jest to ustalenie położenia wskazów przyrządu pomiarowego w zależności od odpowiedniej wartości wielkości mierzonej [3].

Należy mieć pełną świadomość, że wpisanie terminu „wzorcowanie" do procedury czy też odpowiedniego harmonogramu sprawdzeń, powoduje określone konsekwencje. Wyposażenie może podlegać sprawdzeniom bieżącym, okresowym i nadzwyczajnym. Sprawdzenie bieżące, wykonywane każdego dnia, w którym jest używane, może obejmować sprawdzenie jego kompletności, stanu fizycznego itp. Sprawdzenia okresowe, mające na celu wyeliminowanie możliwości użytkowania wyposażenia o nieodpowiedniej charakterystyce, powinny być planowane (harmonogram sprawdzeń) i obejmować sprawdzenie stanu fizycznego i działania, ale również sprawdzenie podstawowych jego charakterystyk (np. liniowość wzmocnienia, stosunku sygnału do szumu, czasu odpowiedzi itp.).

Częstotliwość sprawdzeń okresowych ustala się na podstawie odpowiednich norm lub wytycznych producenta. Powinny być również uwzględniane warunki i intensywność eksploatacji wyposażenia oraz doświadczenia związane z badaniami.
Laboratorium powinno mieć opracowany program wzorcowania. Zaleca się, aby obejmował on system dotyczący wyboru, użytkowania, wzorcowania, sprawdzania i konserwowania próbek wzorcowych (wzorców) i próbek odniesienia oraz wyposażenia do badań, jak również procedurę wzorcowania.

W przypadku badań defektoskopowych, znaczący wpływ na dokładność i miarodajność wyników badań mają urządzenia i aparatura badawcza, sondy i głowice badawcze, podstawowe materiały do badań oraz próbki wzorcowe i próbki odniesienia. Z grupy tej jedynie próbki wzorcowe i próbki odniesienia mogą podlegać wzorcowaniu. Natomiast urządzenia i aparatura badawcza, sondy i głowice badawcze, podstawowe materiały do badań, nie mogą być "wzorcowane", ponieważ powiązanie z wzorcami jednostek miar w ich przypadku nie ma zastosowania.

Przyrządy pomiarowe zaś, stosowane bezpośrednio w badaniach defektoskopowych, a więc miary, suwmiarki, luksomierze, densytometry itp., a także przyrządy służące do pomiarów warunków środowiskowych - powinny być wzorcowane, jeśli niepewność wyniku badania związana z ich wzorcowaniem stanowi ułamek całkowitej niepewności badania.

\section{Dokumentowanie badań - czyli sprawozdanie czy protokół?}

Wyniki każdego badania powinny być przedstawione w sprawozdaniu z badania w sposób jasny i jednoznaczny. "Sprawozdanie" jest szerszym pojęciem niż „protokół”. Sprawozdanie powinno zawierać wszelkie informacje wymagane przez klienta (ustalenia, wymagania, kryteria oceny), odniesienia do dokumentów takich jak procedury badawcze czy normy badań, a także inne informacje wymagane przez PN-EN ISO/IEC 17025.

Powszechnie przyjmuje się, że protokół jest skróconą formą sprawozdania. Wymagania dotyczące minimalnej zawartości protokołu z badania określają normy badań. Zestawienie wymagań zawartości protokołów badań wg norm badań nieniszczących zawiera tablica III.

Częstą praktyką jest wydawanie protokołów z badań jako uproszczoną formę sprawozdania, szczególnie gdy badania wykonywane są na potrzeby wewnętrzne.

\section{Laboratorium uznane - czyli jakie?}

Urząd Dozoru Technicznego (UDT) realizuje zadania związane z wykonywaniem dozoru technicznego w zakresie określonym w ustawie o dozorze technicznym. Dozorem technicznym są określone ustawą działania zmierzające do zapewnienia bezpiecznego funkcjonowania urządzeń technicznych. Zapleczem badawczo-ekspertyzowym UDT jest Centralne Laboratorium Dozoru Technicznego (CLDT). Wyniki badań prowadzonych przez CLDT wykorzystują inspektorzy UDT podczas wykonywania czynności dozoru technicznego.

Zakłady uprawnione do wytwarzania, naprawy lub modernizacji urządzeń technicznych oraz wytwarzania materiałów i elementów stosowanych do ich modernizowania lub naprawiania, muszą mieć możliwość wykonywania badań niszczących i nieniszczących w laboratorium własnym lub w laboratorium uznanym przez właściwy organ dozoru technicznego. Biorąc pod uwagę odpowiedzialność inspektorów UDT za decyzje podejmowane na podstawie ich wyników, to UDT musi akceptować laboratoria i wyniki ich badań.

Proces uznawania laboratorium jest wieloetapowy, a rozpoczyna się, gdy laboratorium składa wniosek o uznanie. 
Tablica III. Wymagana treść protokołów z badań wykonanych poszczególnymi metodami

Table III. Report content for vary NDT testing methods

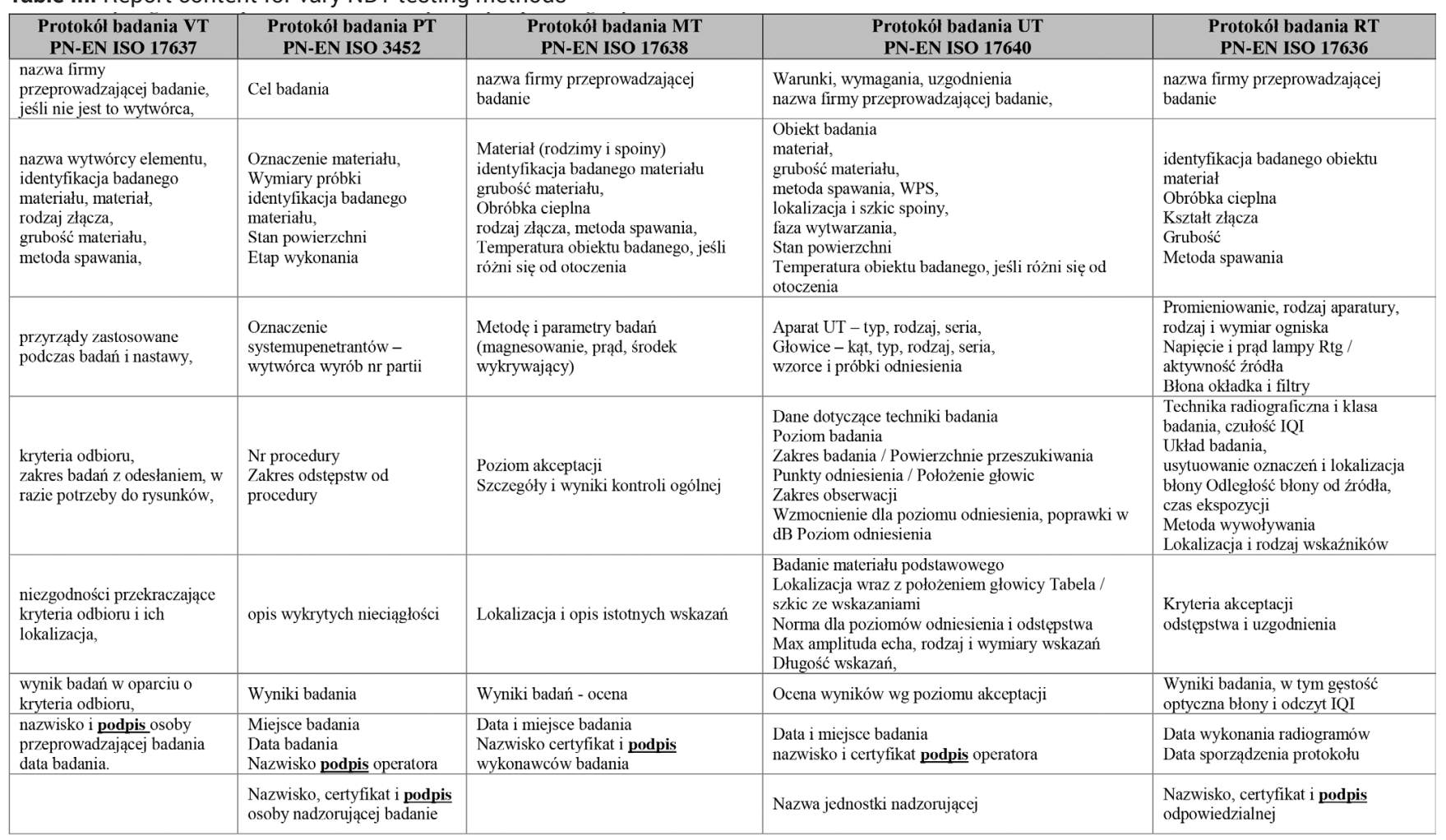

Do wniosku należy dołączyć:

- zakres badań (wykaz metod badawczych, badanych obiektów, zakres badanych cech),

- Księgę jakości laboratorium,

- Procedury / instrukcje ogólne i badawcze wynikające z wymagań PN-EN ISO/IEC 17025

W trakcie oceny, mającej na celu sprawdzenie spełnienia wymagań normy PN-EN ISO/IEC 17025 oraz praktycznych umiejętności laboratorium, szczególną uwagę zwraca się na udokumentowanie kompetencji i kwalifikacji personelu, aktualność dokumentów potwierdzających nadzór metrologiczny nad wyposażeniem oraz praktyczne umiejętności personelu laboratorium, oceniane przez zespół oceniający przy wykonywaniu i dokumentowaniu wyników badań.

Spośród wielu laboratoriów uznanych, podczas oceny w nadzorze, znakomita większość uzyskuje rozszerzenie lub przedłużenie ważności uznania. Niekiedy jednak, w wyniku oceny rejestruje się wiele spostrzeżeń. Ścisła współpraca członków zespołów oceniających z personelem laboratorium owocuje bieżącym eliminowaniem „niedociągnięć", a poważniejsze z nich, kwalifikowane jako spostrzeżenia - wymagają zadeklarowania przez laboratorium działań naprawczych. Często zdarza się, że podczas badania rutyna bierze górę, a opracowywany protokół, zawiera pewne nieścisłości.

Biorąc pod uwagę ogólne wymagania dotyczące kompetencji laboratoriów badawczych, normy badań nieniszczących oraz doświadczenia zebrane w ramach prowadzonych ocen laboratoriów, powtarzające się najczęściej spostrzeżenia lub uwagi dotyczą samego prowadzenia badania oraz protokołowania i opracowywania sprawozdań. Aby uniknąć w swoim laboratorium błędów i nieprawidłowości, warto mieć na uwadze te, które omówiono poniżej.

Badania penetracyjne i magnetyczno-proszkowe, należą do metod badań powierzchniowych, zatem ich wynik jest najbardziej uzależniony od warunków środowiskowych podczas badania. Mowa tu o nieostrożnym prowadzeniu badania i postępowaniu z obiektem do badań, skutkującym fałszywymi wskazaniami. Wskazania fałszywe powstające podczas badania penetracyjnego techniką barwną są spo- wodowane najczęściej nieprawidłowo przeprowadzonym zmywaniem penetranta. Do innych przyczyn powodujących wskazania fałszywe można zaliczyć: odciski palców zanieczyszczonych penetrantem barwnym, kontakt lub tarcie dwu elementów, z których z jednego na drugi przeniesiono ślady penetranta, włókna używanych tkanin do zmywania nadmiaru penetrantu.

Pośpiech i nieuwaga często też powodują, że wskazania rzeczywiste, które jednak nie pochodzą od nieciągłości, są niewłaściwie interpretowane. Należy pamiętać, iż mogą to być konstrukcyjnie zamierzone nieciągłości. Większość z tych wskazań łatwo rozpoznać, np. karby konstrukcyjne, miejsca spawania punktowego itp. Zwykle mają regularne kształty geometryczne i na ogół nie sprawiają problemów interpretacyjnych, szczególnie w przypadkach, gdy operator posiada doświadczenie i odpowiednie dane na temat badanego obiektu.

Protokoły z badań magnetyczno-proszkowych często pomijają informację na temat sposobu magnesowania, czy odmagnesowania próbki/obiektu.

W odniesieniu do metod objętościowych, nieuważne wykonywanie badania może pociągać za sobą szereg poważniejszych konsekwencji, choćby ze względu na fizykę tych metod. Złożoność badania ultradźwiękowego często powoduje, że dobierane są nieodpowiednie poziomy badania, czułość badania i niewłaściwie ocenia się wyniki, względem przyjętego poziomu oceny.

Poziom czułości badania (wyrażony w dB i określony np. jako DSR) - w przypadku badań wykonywanych na danym obiekcie okresowo lub cyklicznie, powinien być w każdym przypadku ten sam. Przykładowo, niezamnierzone zwiększenie wielkości reflektora odniesienia jest równoznaczne ze zmianą czułości i poziomu badania. Często również zdarza się, że poprawki na straty przejścia wynikające ze stosowanej techniki, są przepisywane niejako z automatu, zapominając o tłumieniu materiału, geometrii głowicy, czy rozbieżności wiązki. Należy pamiętać, że nie uwzględnienie poprawek wzmocnienia może wiązać się ze spadkiem wysokości echa nawet o $6 \mathrm{~dB}$, co odpowiada spadkowi 
połowicznemu, a wówczas część wskazań może znaleźć się poniżej poziomu rejestracji!

Większość laboratoriów wykonuje badania radiograficzne $\mathrm{w}$ terenie. Warunki poligonowe nie sprzyjają niekiedy właściwemu przygotowaniu się do badań. Konsekwencją są omyłki lub błędy w zapisach i obliczeniach, a dalej złe parametry badania techniką $X$, tj. maksymalne napięcie na lampie rentgenowskiej [kV], czas naświetlania [min], odległość ogniskowej.
Mimo wszechobecnego pośpiechu, warto zweryfikować czy została wykonana wymagana ilość ekspozycji, a strefy badane pokrywają się, co powinno być uwidocznione na kolejnych błonach. Ilość ekspozycji powinna odpowiadać liczbie radiogramów dołączonych do protokołu. Pokrycie strefy badanej (nakładanie się błon) weryfikuje się za pomocą znaczników lokalizujących, przy czym upewniamy się, czy znacznik widoczny jest na obu radiogramach odpowiadających przylegającym do siebie obszarom.

\title{
Podsumowanie
}

Spełnienie wymagań dotyczących kompetencji laboratoriów badawczych stanowi domniemanie zapewnienia najwyższych standardów jakości badań nieniszczących. Ocena prowadzona przez podmioty zewnętrzne stanowi źródło informacji, co można lub trzeba poprawić, jakie słabe strony można wzmocnić. Jednak udział zewnętrznych auditorów nie jest jedynym sposobem nadzorowania jakości wykonywanych w laboratorium badań.

Monitorowanie (nadzorowanie jakości badań) w laboratoriach NDT może obejmować stosowanie próbek odniesienia z naturalnymi lub sztucznymi nieciągłościami, udział w porównawczych badaniach międzylaboratoryjnych lub w programach badania biegłości, powtarzanie badań przy wykorzystaniu tych samych lub innych metod NDT, powtórne badanie przechowywanych obiektów z nieciągłościami naturalnymi, powtórną ocenę przechowywanych radiogramów przez personel tego samego laboratorium itp. Stosowne udokumentowanie powyższych czynności, jest jednym z dowodów potwierdzających kompetencje.

W artykule wskazano również bardzo istotny element zapewnienia jakości wyników badań, jakim jest personel, jego kwalifikacje, wiedza i doświadczenie. Ważne zatem jest nie tylko, czy personel wykonujący badanie posiada odpowiednie kwalifikacje, lecz także czy nadzór nad badaniami, a w szczególności nad zatwierdzaniem wyników, prowadzi kompetentny personel.

Te kluczowe aspekty systemu badań nieniszczących, a w szczególności umiejętności praktyczne personelu i swoiste obycie w badaniach NDT są przedmiotem oceny kompetencji laboratorium, choćby podczas uznawania laboratoriów. Właściwe udokumentowanie i przedstawienie wiarygodnych dowodów na spełnienie wymagań PN-EN ISO/IEC 17025 pozwala na stwierdzenie, że dane laboratorium jest kompetentne, a wykonywane w nim badania są najwyższej jakości.

\section{Literatura}

[1] Ustawa z dnia 21 grudnia 2000 r. o dozorze technicznym (Dz. U. z 2013, poz. 963 ze zm.).

[2] PN-EN ISO/IEC 17025:2005 Ogólne wymagania dotyczące kompetencji laboratoriów badawczych i wzorcujących
[3] "Międzynarodowy Słownik Podstawowych i Ogólnych Terminów Metrologii"- Wydanie polskie; GUM; Warszawa; 1995.

\section{ZAMÓW NEWSLETTER}

\author{
Zapraszamy Państwa do zapisania się na bezpłatny \\ NEWSLETTER Przeglądu Spawalnictwa, \\ w tym celu należy wysłać e-mail z tematem \\ “NEWSLETTER” na adres: redakcja@pspaw.pl
}

\section{SpaWnirzeglad}

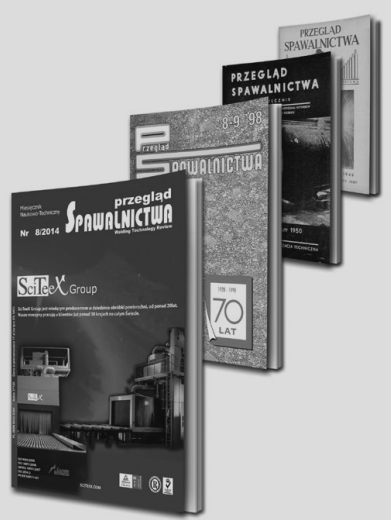

